Jurnal Pendidikan Matematika : Judika Education

Volume 2, Nomor 1, Januari-Juni 2019

e-ISSN : 2614-6088

p-ISSN : 2620-732X

DOI: https://doi.org/10.31539/judika.v2i1.759

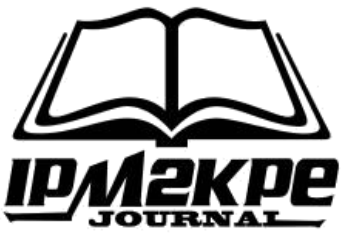

\title{
PENGGUNAAN KUACI PADA PEMBELAJARAN VOLUME BOLA DI KELAS
}

\author{
Widiawati $^{1}$, Helni Indrayati ${ }^{2}$, Herdiyan Siswanto ${ }^{3}$ \\ STKIP Muhammadiyah Pagaralam ${ }^{1,2,3}$ \\ widiawati141@gmail.com ${ }^{1}$
}

\begin{abstract}
ABSTRAK
Tujuan penelitian ini adalah untuk mengetahui lintasan belajar siswa pada materi volume bola menggunakan kuaci di Kelas IX. Metode penelitian, menggunakan desain Validation Study dengan melibatkan 38 siswa kelas IX SMP PGRI Pagaralam. Tahapan design research dalam pembelajaran terdiri dari tiga fase yaitu persiapan untuk percobaan, percobaan desain, dan analisis retrospektif. Pembelajaran yang dilakukan melalui tiga aktivitas yang terdiri dari mengamati bunga matahari, mengambil biji (kuaci) bunga matahari, dan membungkus kuaci sesuai dengan pendekatan PMRI pada materi volume bola. Hasil penelitian menunjukkan bahwa siswa dapat memahami konsep volume bola dengan menyelesaikan serangkaian aktivitas-aktivitas tersebut. Selain itu, siswa mempunyai strategi-strategi sendiri dalam menyelesaikan masalah di setiap aktivitas hingga mengungkapkannya dalam bentuk abstrak. Simpulan, penggunaan kuaci dalam pembelajaran volume bola memberikan hasil yang positif bagi siswa dalam memahami permasalahan yang berkaitan dengan kehidupan real sesuai dengan pendekatan PMRI
\end{abstract}

Kata kunci: Design Research, Kuaci, PMRI

\section{ABSTRACT}

The purpose of this study was to determine the trajectory of student learning on ball volume using quaci in Class IX. The research method, using a Validation Study design involving 38 students of class IX SMP Pagaralam PGRI. The stages of design research in learning consist of three phases: preparation for the experiment, design experiment, and retrospective analysis. Learning is carried out through three activities consisting of observing sunflowers, taking sunflower seeds, and wrapping them in accordance with PMRI's approach to ball volume material. The results showed that students could understand the concept of ball volume by completing a series of these activities. In addition, students have their own strategies in solving problems in each activity to express it in abstract form. Conclusion, the use of quaci in learning volumes of ball gives positive results for students in understanding problems related to real life in accordance with the PMRI approach.

Keywords: Design Research, Kuaci, PMRI 


\section{PENDAHULUAN}

Bola merupakan bangun ruang sisi lengkung yang mempunyai luas dan volume. Curry \& Outhred (2005) menyatakan bahwa volume dapat diukur dengan cara Filling (pengisian dengan cairan berulang-ulang) dan Packing (pengisian dengan pengemasan sesuai dengan susunan tiga dimensi secara berulang). Volume bola dapat diukur dengan cara pengisisan-pengisian tersebut.

Widiawati, Rahayu \& Widyaningrum (2018) mengungkapkan bahwa materi volume bola sangat penting karena materi tersebut menunjukkan keterkaitan antar materi yang satu dengan yang lainnya seperti perbandingan dan lingkaran. Adanya pemahaman materi perbandingan dan lingkaran, maka akan mempermudah dalam mempelajari materi volume bola.

Walaupun materi volume bola sangat penting, tetapi masih banyak siswa yang mengalami kesulitan dalam menentukan volume bola. Syahbana (2013) mengemukakan bahwa siswa tidak bisa memahami rumus volume bola dikarenakan siswa terbiasa menghafal rumus. Selain itu, Takaria (2017) mengatakan bahwa kebanyakan siswa hanya menerapkan rumus volume tanpa memahami konsep dasarnya. Adanya pengetahuan rumus volume saja menyebabkan siswa tidak memahami konsep dasarnya. Dengan demikian, seorang guru harus mampu menciptakan kondisi pembelajaran yang mengajak siswa untuk aktif dengan menemukan konsep-konsep dasar matematika khususnya volume bola.

Salah satunya adalah guru harus merancang pembelajaran dengan menggunakan pendekatan Pendidikan Matematika Realistik Indonesia (PMRI).

PMRI merupakan suatu pendekatan yang mengajak siswa belajar dengan menghubungkan materi pembelajaran dengan dunia nyata yang dekat dengan siswa itu sendiri. Hasil penelitian Juwita, Putri \& Somakim (2015) menunjukkan bahwa siswa sangat tertarik dalam belajar volume bola karena siswa menemukan sendiri konsep dasar dari volume bola dengan menggunakan buah semangka melalui pendekatan PMRI sehingga sangat memberikan pengaruh yang signifikan.

Selain itu, hasil penelitian Kurino (2017) menunjukkan bahwa siswa dapat lebih memahami materi volume bangun ruang dengan menggunakan PMRI berbantuan alat peraga. Untuk itu, PMRI dapat meningkatkan hasil belajar siswa dan menambah ketertarikan siswa dalam belajar matematika sehingga tidak bosan.

Berdasarkan uraian di atas, tujuan penelitian ini adalah untuk mengetahui lintasan belajar siswa pada materi volume bola menggunakan kuaci di Kelas IX.

\section{METODE PENELITIAN}

Penelitian ini merupakan design research type validation studies bertujuan untuk mengembangkan Local Instruction Theory (LIT) yang merupakan produk akhir dari analisis hasil pembelajaran dan HLT serta pengimplementasiannya. Dalam hal ini, pembelajaran yang dilakukan sesuai dengan PMRI pada materi 
volume bola menggunakan kuaci. Widiawati, Marzal \& Juwita (2018) menyatakan bahwa pembelajaran dalam design research berupa serangkaian aktivitas siswa yakni dugaan-dugaan strategi dan pemikiran siswa yang dapat berkembang selama proses pembelajaran yang menunjukkan siklus proses berulang.

Menurut Gravemeijer \& Cobb (2006), design research terbagi menjadi tiga fase utama, yaitu persiapan untuk percobaan, percobaan desain, dan analisis retrospektif. Teknik pengumpulan data menggunakan dokumentasi (rekaman video, Lembar Aktivitas Siswa (LAS), catatan Lapangan).

\section{HASIL PENELITIAN}

Penelitian ini dilakukan pada siswa kelas IX dengan menerapkan pendekatan PMRI menggunakan konteks kuaci dengan melalui beberapa aktivitas dalam pembelajaran. Pembelajaran dengan pendekatan tersebut terdiri dari tiga aktivitas yaitu mengamati bunga matahari, mengambil biji (kuaci) bunga matahari, dan membungkus kuaci. Aktivitas-aktivitas tersebut dapat diuraikan sebagai berikut;

\section{Aktivitas 1 Mengamati Bunga Matahari}

Pada aktivitas ini, siswa melakukan pengamatan pada bunga matahari. Bunga matahari tersebut memiliki biji-biji (kuaci) pada bunga tabungnya yang berbentuk setengah bola. Di sini, setiap kelompok siswa diberikan LAS 1 untuk memandu pemahaman siswa dan bunga matahari sebagai bahan pengamatan. Setiap kelompok siswa mengamati bunga tabung (kumpulan bijibiji/kuaci) yang ada pada bunga matahari seperti pada gambar 1 .

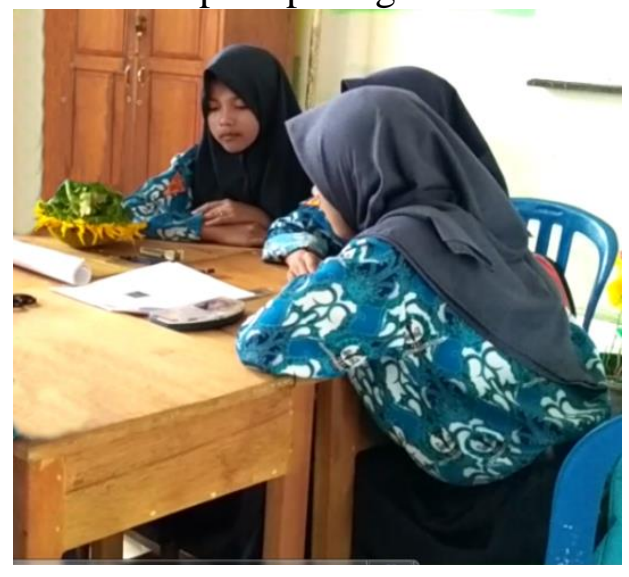

Gambar 1. Mengamati Biji/Kuaci Bunga Matahari

Pada Gambar 1, siswa melakukan pengamatan terhadap bunga matahari. Dalam kegiatan ini, guru dan siswa melakukan percakapan sesuai dengan hasil pengamatan.

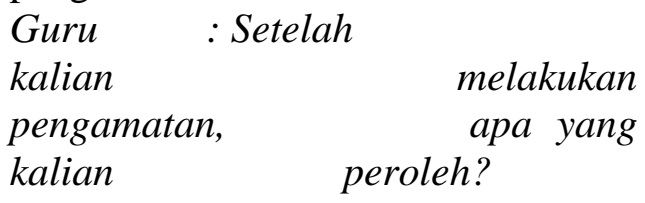

Siswa 1 : Biji-bijinya

bentuknya bulat...

Siswa 2 : Iya, mirip seperti setengah bola...

Dari percakapan di atas, siswa dapat memahami bahwa bentuk dari kuaci bunga tabung matahari berbentuk setengah bola. Ini menjadi awal pemahaman siswa mengenai volume bola

Dengan pemahaman tersebut, siswa memperoleh pengetahuan bahwa tabung kuaci bunga matahari merupakan volume atau isi setengah bola. 


\section{Aktivitas 2 Mengambil Biji (Kuaci) Bunga Matahari}

Pada aktivitas ini, siswa mengambil biji/kuaci dari bunga tabung pada bunga matahari sampai habis. Dalam hal ini, siswa harus mengukur diameter bunga tabung terlebih dahulu. Setelah mengukur diameternya, maka siswa langsung memisahkan atau mengambil bijibijinya dari bunga tersebut. Aktivitas ini dapat dilihat pada gambar 2 .

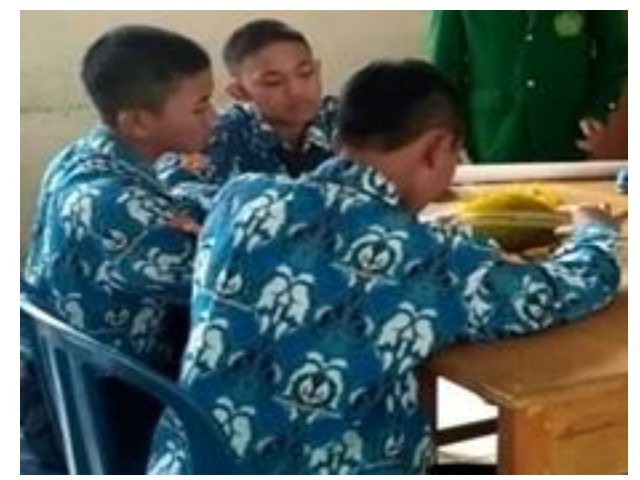

Gambar 2. Siswa Mengukur Diameter Bunga Tabung dari Bunga Matahari

Pada gambar 2 terlihat bahwa siswa sedang mengukur diameter dari bunga tabung. Dalam pengukuran tersebut terjadi percakapan.

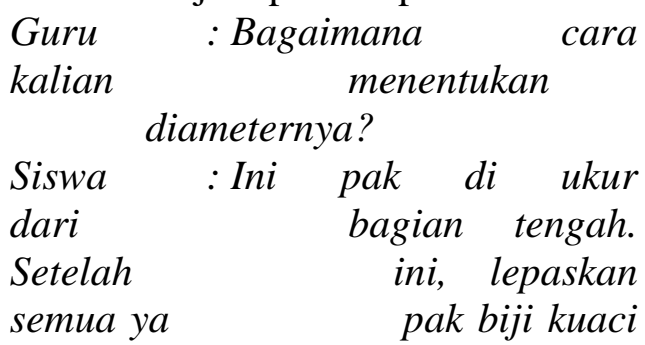

nya?

Guru : Iya pisahkan semuanya.

Dari percakapan di atas, siswa dapat menentukan diameter bunga tabung dengan menggunakan penggaris. Setelah menentukan diameternya, siswa mengambil biji-biji bunga tabung sampai habis.

\section{Aktivitas 3 Membungkus Kuaci}

Pada aktivitas 3, siswa membungkus kuaci/biji-biji yang diambil dari aktivitas 2. Sebelum membungkus kuaci, siswa harus membuat wadah berbentuk kerucut untuk membungkus kuaci menggunakan pengukuran diameter bunga tabung. Diameter kerucut sama dengan diameter bunga tabung dan tinggi kerucut sama dengan setengah diameter (jari-jari) bunga tabung. Hal ini dapat dilihat pada gambar 3 .

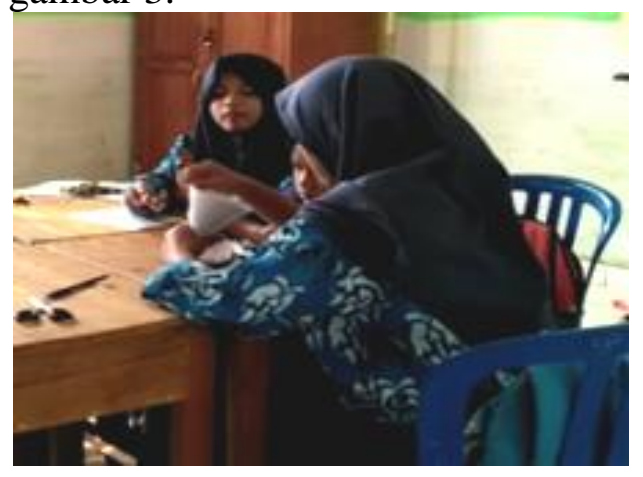

Gambar 3. Siswa Membuat Kerucut

Dari gambar 3, siswa dapat membuat kerucut menggunakan kertas karton. Dalam kegiatan ini, terjadi komunikasi antara guru dan siswa.

$\begin{array}{lrr}\text { Guru } & \text { : Buat } \quad \begin{array}{r}\text { lingkaran } \\ \text { sesuai } \\ \text { bunga }\end{array} & \text { dengan jari-jari } \\ \text { jari- } & \text { tabung. Berapa } \\ \text { Siswa } & \text { jarinya? } \\ \text { Guru Jari-jarinya } 8 . . . \\ \text { gambar } & \text { Silahkan kalian } \\ \text { lingkarannya... }\end{array}$

Dari percakapan di atas, siswa membuat kerucut berdasarkan jarijari yang mereka peroleh dari jari-jari bunga tabung. Dalam hal ini, siswa membuat kerucut sesuai dengan pengukuran pada diameter bunga tabung yang mereka amati.

Setelah siswa membuat 
kerucut, mereka menggunakan kerucut tersebut untuk membungkus kuaci. Dari kuaci yang sudah diambil atau dipisahkan dari bunga tabung, siswa dapat memperoleh dua bungkus kuaci dengan wadah kerucut yang telah dibuat sebelumnya. Hal ini dapat dilihat pada gambar 4 .

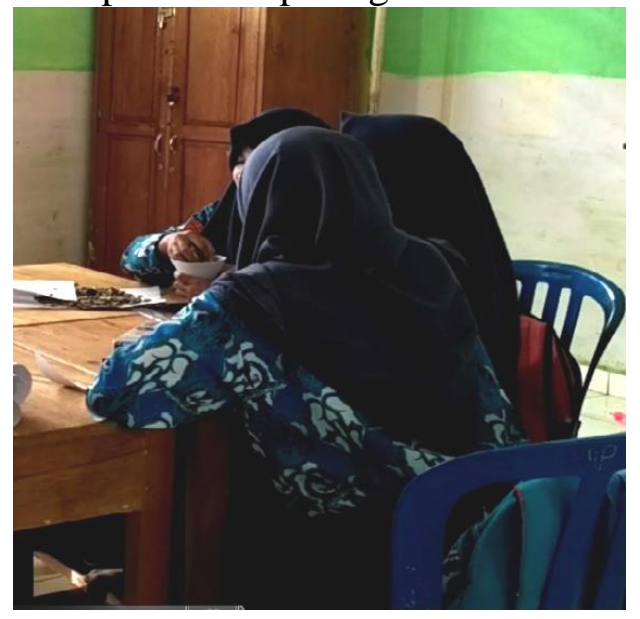

Gambar 4. Siswa Membungkus Kuaci Pada gambar 4, siswa memasukan kuaci ke dalam wadah kerucut yang telah mereka buat sendiri. Dalam proses tersebut, siswa memperoleh dua bungkus kerucut yang terisi penuh oleh kuaci seperti terlihat pada percakapan berikut.

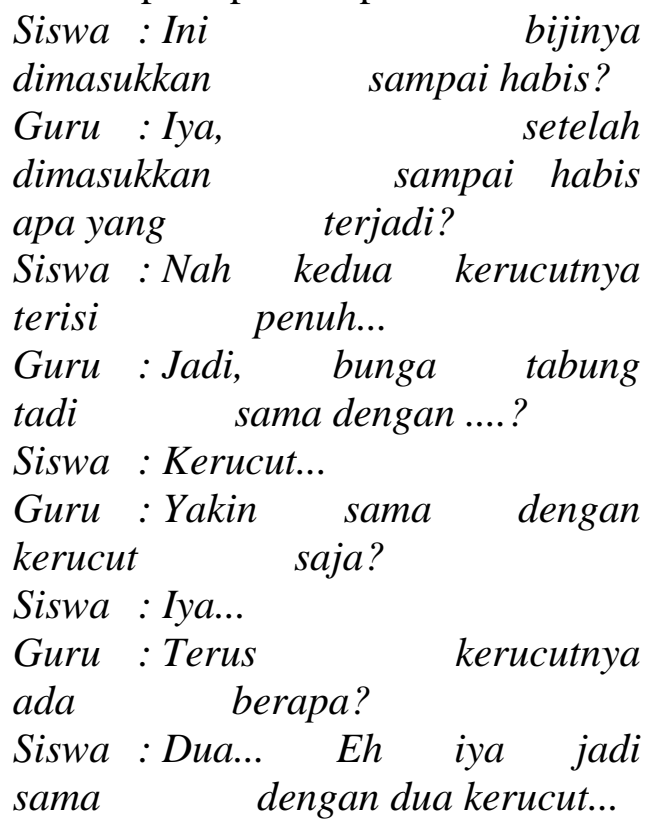

Dari percakapan di atas, siswa dapat memahami bahwa dalam bunga tabung yang berbentuk setengah bola setelah dipisahkan dalam bentuk kuaci akan menghasilkan dua kerucut. Di mana jari-jari dan tinggi kerucut sama dengan jari-jari bunga tabung. Ini berarti bahwa volume bunga tabung (setengah bola) sama dengan volume kerucut.

Dengan demikian, dari pembelajaran yang telah dilakukan dengan melalui aktivitas-aktivitas di atas, siswa dapat memahami konsep dari volume bola. Konsep tersebut diperoleh dari konsep setengah bola dari bunga tabung matahari yang menghasilkan dua bungkus kuaci dengan wadah kerucut.

\section{PEMBAHASAN}

Desain lintasan belajar yang telah dirancang dan dilakukan oleh peneliti untuk memahami konsep volume bola melalui bunga tabung meliputi tiga aktivitas yaitu mengamati bunga matahari, mengambil biji (kuaci) bunga matahari, dan membungkus kuaci. Pembelajaran ini berdasarkan implementasi dari PMRI dengan rancangan pada setiap aktivitasnya sesuai dengan lima karakteristik PMRI.

Karateristik pertama adalah
penggunaan konteks. Dalam
pembelajaran ini menggunakan
kuaci. Kuaci tersebut merupakan
konteks nyata yang sering ditemui
oleh siswa sebagai makanan ringan
ataau jajanan yang biasa dikemas
dengan aneka ragam bentuk
bungkusnya. Kuaci tersebut berasal
dari bunga matahari yang
mempunyai bunga tabung (kumpulan


dari biji-biji/kuaci).

Siswa bahkan telah mengetahui dan memahami bahwa bunga tabung dapat membantu pembelajaran pada materi volume bola dapat menyelesaikan masalah volume bola dalam pembelajaran matematika di sekolah. Melalui aktivitas ini, siswa melakukan percobaan pengisian didalam LAS 1 dan LAS 2 serta menyelesaikan masalah. Kegiatankegiatan ini memberikan hal yang baru dan berbeda sehingga siswasiswi merasakan pembelajaran matematika di kelas menjadi lebih bermakna.

Karateristik kedua adalah penggunaan model. Dari karakteristik ini, siswa mengamati bentuk dari bunga tabung pada aktivitas 1 dan aktivitas 2 yaitu mengambil biji (kuaci) bunga matahari yang merupakan bentuk level kedua yaitu model for. Pada level model for terlihat pada saat siswa melakukan pembuatan kerucut dan pembungkusan kuaci menggunakan kerucut tersebut. dengan volume bola. Dengan mengenal dan mengamati kuaci dari bunga matahari menunjukkan bahwa siswa telah berada pada level formal di mana siswa telah memperoleh notasi yang bersifat abstrak.

Karateristik yang ketiga yaitu pemanfaatan hasil kontruksi siswa. Hal ini terlihat pada proses pelaksanaan dari tiga aktivitas yang telah dilakukan. Guru memberi kebebasan kepada siswa dalam mengungkapkan jawaban pertanyaan menggunakan strategi mereka masing-masing. Strategi yang ditemukan adalah dalam pengukuran diameter dari bunga tabung. Pengukuran tersebut ada yang menggunakan penggaris, tali, ataupun lidi. Selain itu dalam pembuatan lingkaran kerucut, ada yang menggunakan jangka, tali, atau titik-titik dengan pengukuran penggaris.

Selanjutnya karateristik yang keempat adalah interaktivitas. Interaktivitas tidak hanya terjadi antara guru dan siswa tetapi juga dengan sesama siswa. Interaksi antara guru dan siswa dalam setiap aktivitas selalu terjadi. Guru melakukan proses pembimbingan kepada setiap kelompok yang terlihat percakapan-percakapan yang telah dilakukan.

Karateristik yang terakhir adalah keterkaitan. Pada pembelajaran ini berkaitan dengan konsep lingkaran, kerucut, dan perbandingan. Selain itu, konsep operasi hitung juga sangat berhubungan.

Berdasarkan karakteristikkarakteristik tersebut menunjukkan bahwa siswa telah melakukan seluruh rangkaian aktivitas dari aktivitas pertama sampai terakhir sesuai dengan pendekatan PMRI. Ini berarti bahwa siswa telah melakukan pembelajaran dalam memahami konsep volume bola dengan baik dan siswa dengan mudah dapat mengetahui konsep dasar dari volume bola itu sendiri sehingga siswa tidak identik dengan menghapal rumus tetapi menemukan rumus itu sendiri. Oleh karena itu, mereka mudah mengingatnya tanpa harus menghapal dan bisa menerapkannya dalam penyelesaian masalah yang berkaitan dengan volume bola. 


\section{SIMPULAN}

Penggunaan kuaci dalam pemahaman konsep volume bola memberikan pengaruh yang positif. Hal ini dikarenakan siswa dilibatkan secara langsung dalam pembelajaran dan mengaitkan materi sesuai dengan kehidupan real siswa.

Lintasan belajar siswa pada materi volume bola menggunakan kuaci yang terdiri dari aktivitasaktivitas seperti mengamati bunga matahari, mengambil biji (kuaci) bunga matahari, dan membungkus kuaci membantu siswa untuk memahami konsep volume bola sehingga proses pembelajaran menjadi lebih bermakna.

\section{DAFTAR PUSTAKA}

Curry, M., \& Outhred, L. (2005). Conceptual Understanding of Spatial Measurement. Building Connections: Theory, Research and Practice, 265-272.

Gravemeijer, K. \& Cobb, P. (2006). Design Research from a Learning Design Perspective. Dalam

Juwita, H., Putri, R.II. \& Somakim. (2015). Peranan Buah Semangka dalam Pembelajaran Volume Bola. Jurnal Elemen, 1(2); 130-143.

Kurino, Y.D. (2017). Penerapan Realistic Mathematic Education dalam Meningkatkan Hasil Belajar siswa Kelas V pada Materi Volume Bangun Ruang di Sekolah Dasar. Jurnal Cakrawala Pendasi 3 (2); 3747.
Syahbana, A. (2013). Alternatif Pemahaman Konsep Umum Volume Suatu Bangun Ruang. Edumatica 3 (2); 1-7.

Takaria, J. (2017). Pemahaman Konsep Volume Bangun Ruang Melalui Hukum Kekekalan Isi: (Apakah Anak Saya Sesuai dengan Teori Piaget). Jurnal Pedagogika dan Dinamika Pendidikan 7 (2); 79-89.

Widiawati, Marzal, D., \& Juwita, H. (2018). Desain Pembelajaran Garis dan Sudut dengan Konteks Pagar Buluh di Kelas VII. Journal of Mathematics Science and education 1(10); 118-130.

Widiawati, Rahayu, C., \& Widyaningrum, I. (2018). Penerapan Metode Penemuan Terbimbing pada Materi Luas Permukaan dan Volume Bola di Kelas IX. Jurnal Akrab Juara 3 (3); 93-101. 